\title{
The Denial of the Idea of Personal Identity as a Result of Hume's Skepticism
}

\section{Hume’un Skeptisizminin Bir Sonucu Olarak Kișisel Özdeșlik Tasarımının Reddi}

\section{NURTEN ÖZTANRIKULU ÖZEL}

Independent Researcher

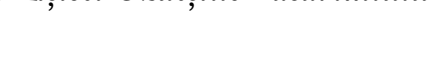




\section{Introduction}

Today, "personal identity" is a problem that is mostly handled - by referencing to each other - by philosophy, theology and psychology. This problem is defined in philosophy by the claim that "of characterizing the conditions given when a person existing at one time, and a person existing at another time, turns out to be one and the same person" (Iannone, 200I: 256). In other words, personal identity includes the theses claiming that the "a" person at the " $x$ " time is the same person with the " $b$ " person at the " $y$ " time. When the history of philosophy is considered in this perceptive, it is seen that there are two approach types to the problem of personal identity. One of these is the rationalist or metaphysical approach which deals with the personal identity as the extension of the soul and the substance. The other is the skeptical approach which object to rationalist and metaphysical approach based on the nature of the mind. The skeptical thoughts of Hume on the idea of personal identity will be dealt with in the present study. ${ }^{\mathrm{I}}$

Hume only discusses personal identity in the "Personal Identity" section of the book of his called "A Treatise of Human Nature" and in the Appendix section he wrote to his book. The "Personal Identity" section (Treatise, I.4.6), which is the main part of the discussion, was written after the sub-section "Of the Immateriality of the Soul" (Treatise, I.4.5). In this respect, it is seen that Hume continued the debate of personal identity as the continuance of the previous section, which Thiel also claimed. According to Thiel, the investigation of personal identity in I.4.5. is related with "the issue of the simplicity and indivisibility of the human soul as substance". In this section, Hume defended that we could not have an idea of mental substance. As a continuance of this, in Treatise I.4.6, he dealt with the question "How does our belief arise that we exist as one and the same thing through time?" (Thiel, 20II: 387 ). For this reason, it may be claimed that the philosophical outcomes of Hume on the soul and substance were influential on Hume's thoughts about personal identity. Swain claimed that the views of Hume on personal identity may not be considered as separate from his views on other metaphysical issues. In order to under-

I The strongest commentator who argues that Hume is a skeptic about personal identity among Hume's commentators is Penelhum (See Penelhum I975: 389-409). 
stand Hume, she mentioned that it was necessary to understand Book I of Treatise (Swain, 2006: 133). Although Swain pointed out to the causality and the external objects, considering Hume's thoughts on substance and soul will enable us to understand the context of the topic better. However, it must be clearly mentioned that the views of Hume on soul and substance will not be investigated in this present study. Although the explanation of personal identity with a continuous "self" belief established its relation with the metaphysical one, the substance and soul issues will be excluded from this study, because the things that must be focused on are the "self" and "identity". When Hume examined self and identity, since he meanwhile investigated the possibility of a mental substance, the results he concluded include an answer against metaphysical claims. In this respect, Capaldi seems to be right in proclaiming Hume as the first philosopher who fought successfully against the belief in "substantial self" (Capaldi, 1975: 139). No doubt, the biggest basis of the success of Hume was the "perception theory", and parallel to this, the "bundle theory". Hume tried to save self and identity from metaphysical elements, which is consistent with his own philosophy.

\section{The Idea of Self}

Hume's thoughts on the self are usually discussed in the literature as the main issue of a disagreement and dissatisfaction between Treatise I.4.6 and Appendix. In other respects, some interpreters consider the self as an idea; and focus on the theory of bundle of perceptions. Although there is a "pseudo" dissatisfaction between the two sections for Hume, there are no disagreements, this study can be considered in the category of handling the self as an idea. As a matter of fact, Hume focuses on the idea of a continuous self without suspicion of the existence of the self.

In Hume's philosophy there are two kinds of ideas, which are simple and complex. Simple ideas are ideas that can never be separated in any way. Complex ones, on the other hand, can be distinguished (Hume, I960: 2). For simple ideas, there is a rule holds without any exception. According to this, "every simple idea has a simple impression, which resembles it; and every simple impression a correspondent idea." (Hume, I960: 3). Complex ideas consist of simple ideas. Therefore, every simple 
part of the complex ideas must have a simple impression "mediately or immediately" (Hume, I960: 7). The "first principle" that was formed by Hume for human nature is this one; and all epistemology is built on this principle (Hume, 1960: 7). Hume, who sought the impressions in the origin of ideas by the first principle, continued to examine the ideas until it arrived at the impression that preceded it. According to Hume, "The examination of the impression bestows a clearness on the idea ; and the examination of the idea bestows a like of the idea clearness on all our reasoning." (Hume, I960: 75). For this reason, the examination of the idea of self begins with the examination of how this idea is and whether it has an impression or not.

The idea of self is a complex idea, and at the beginning of the debate, Hume opposes the philosophies that handle this idea as a simple one.

There are some philosophers, who imagine we are every moment intimately conscious of what we call our SELF; that we feel its existence and its continuance in existence; and are certain, beyond the evidence of a demonstration, both of its perfect identity and simplicity. The strongest sensation, the most violent passion, say they, instead of distracting us from this view, only fix it the more intensely, and make us consider their influence on self either by their pain or pleasure (Hume, 1960: 25I).

According to Hume, some philosophers define the "self" as a perfect identity of which we are conscious at every moment, and whose continual existence we feel. When he mentioned "some philosophers", although there were no certain philosophers at whom he pointed, he targets Cartesian philosophers and the other philosophers, i.e. the "metaphysicians", who continued their results. These philosophers' presenting the self together with a perfect identity as a simple idea is the point of objection for Hume. Hume bases the claim that we cannot have the idea of self unlike these philosophers with the "first principle" of his philosophy. As Capaldi pointed out, Hume did not claim that we are not have the idea of self; instead, he claimed that we are not have a simple idea of the self (Capaldi, I995: 628). If he refused the "self", he could not have a debate on personal identity. What he refused was the substantive meanings associated with the idea of self. For Hume, the thing that should be done was clear: inves- 
tigating the impression that was the source of the idea of self, or in other words, finding the "first principle".

It is not possible to answer without "contradiction and absurdity" the question of which impression the idea of self was derived (Hume, I960: 25I). According to Robison, it is absurd to assume that the "self" is an impression; and it is contradictory to claim that we have an impression that does not have an impression (Robison, 1995: 689). It is absurd to think that there is an impression of the self while there must be a certain impression that reveals every "real idea"; because "self or person is not any one impression, but that to which our several impressions and ideas are supposed to have a reference.” (Hume, I960: 25I). So, this is a supposition or an assumption. If this idea is still thought to emerge by an impression, it is necessary that this impression remains stable and the same throughout life because of the continuity and sameness of self. However, "there is no impression constant and invariable" (Hume, I960: 25I). For this reason, "there is no such idea." (Hume, 1960: 252). In this case, claiming that the "self" has a constant and invariable perception is contradictory because it means claiming that it has an impression. In this respect, Hume rejects the idea claiming that there is a simple impression that is the source of the idea of self, on the contrary, he claims that the self is a complex idea. According to Hume, who thought that every simple part of complex ideas must have a simple impression mediately or immediately, simple impressions that form the idea of self or the idea of personal identity are the "impressions of the reflection", which was also mentioned by Capaldi (Capaldi, I995: 63I).

According to Hume, there are two kinds of impressions: impression of sensation and impression of reflexion. We cannot know the reasons that caused that the impression of sensation emerged; and the investigation of the impression of sensation is the work of "anatomists and natural philosophers" (Hume, 1960: 7). The impression of reflexion is derived measure from our ideas. First of all, we experience the impression of sensation; and through it, we perceive heat, cold, thirst, hunger or some kind of pleasure or pain. After the impressions disappear, one copy of these impressions remains in our minds; and this is called "idea". These ideas are recalled by the memory and imagination; and become the source of 
new impressions and ideas (Hume, 1960: 7-8). The thing Hume names as the impression of reflexion is the product of a reflexion on previous impressions of idea; and comes out with the cooperation of the memory and imagination. When the idea of self and personal identity are considered in this context, it seems that these ideas do not originate directly from senses, which was also mentioned by Stroud. (Stroud, I977: II8). No sensory impression is stable and continuous. According to Capaldi:

As an idea the complex idea of the self must be preceded by an impression.

No idea can arise without a preceding impression. [...] Complex ideas do not have a one-to-one correspondence (Treatise, p.3.) No complex idea, including and especially the complex idea of the self, need have a direct analogue in experience. Complex ideas morever, are formed through the creative activity of the mind's association of ideas (Capaldi, 1995: 629).

The idea of self is a product of previous perceptions and experiences reproduced with "the principles of association of imagination". In other words, this idea comes from the series of perceptions created by the impression of sensation. For this reason, we do not have a simple and individual impression of self. This idea is something we think that our various impressions and ideas provide a reference to. The thing that allows this is the contents of the mind, in other words, the perceptions. If an idea of self is to be mentioned, such a idea should be the one that may only be caught by perceptions.

The self becomes explainable by some particular perceptions. "For my part, when I enter most intimately into what I call myself, I always stumble on some particular perception or other, of heat or cold, light or shade, love or hatred, pain or pleasure." (Hume, I960: 252). As the self cannot be perceived without these particular perceptions, they reveal the fact that the continuity of the "self" is incomprehensible. Hume improves this argument of his with his thoughts known in the literature as the "Bundle Theory". The self or mind is "nothing but a bundle or collection of different perceptions, which succeed each other with an inconceivable rapidity, and are in a perpetual flux and movement." (Hume, I960: 254). The mind is almost like a theatre stage on which a lot of perceptions are on display. Perceptions appear and disappear on the stage in a variety (Hume, I960: 253). Every self has a comprehension of the successive of 
its own perceptions; despite this, the unchanging and continuous comprehension of the self is not clear. In other words, the mind is not a substance. However, we still have a tendency to accept the self as a substance or to load identity to successive perceptions. With this tendency, we assume that we have an existence without change and interruption throughout our lives. The problem becomes evident here. If the self is a bundle of different perceptions or "heaps" (Hume, 1960: 207), what is it that brings them together? In other words, why do we think that different and distinguishable perceptions belong to the same, continuous, and unchanging self? This is the question with which Hume investigated why we have an identity and with which he investigated the source of this tendency. With this question, Hume makes an identity analysis, intending to explain his thoughts on "the nature of personal identity" which is popularly discussed in recent years in England (Hume, I960: 259). This analysis is important in that it enables a more detailed development of the personal identity investigation.

\section{The Relation of Identity}

Before Hume's account of personal identity, the identity have been dealt with in detail in Treatise I.4.2. where he questions the belief in the continued and distinct existence of external objects even when are not perceived. Despite the interruption on perceptions, the perception of continuity and unchangeablity in the impressions is formed via the relation of identity. We accept the interrupted perceptions as identical without seeing them as different perceptions (Hume, 1960: 199). In this way, we believe that the external world exists independently and separately from perception. There are two points that attract attention here. The first one is that a continuous idea of self is generated with the relation of identity just like external objects. The second is that the identity is an assumption or belief. When Hume discussed personal identity, he passed again through the path he followed four sections ago and dealt with identity.

Identity is the acceptance of many different objects existing in succession as the same despite their change and interruption in perception (Hume, 1960: 253). Although the mind sometimes notices that the succes- 
sion in the perceptions change and are interrupted, it still imposes a complete identity on it. The ability of the mind in doing this is the imagination. The imagination has the tendency of assuming the variable and interrupted perceptions as invariable and uninterrupted by "an improper sense" (Hume, I960: 255). In actual fact, on the other hand, the thing that is perceived is only the succession of the related objects, that is, the diversity. Imagination causes a mistake by associating them identically. This mistake may be more clearly understood by examining daily experience and observations; because, as a result of such an examination, it may be clearly seen that " the objects, which are variable or interrupted, and yet are suppos'd to continue the same, are such only as consist of a succession of parts, connected together by resemblance, contiguity, or causation." (Hume, 1960: 255). In other words, "all objects, to which we ascribe identity, without observing their invariableness and uninterruptedness, are such as consist of a succession of related objects" (Hume, I960: 255). The relation of resemblance, contiguity and causation "facilitates the transition of mind from one object to another, and renders its passage as smooth as if it contemplated one continu'd object" (Hume, I960: 255). Through these three relationships, imagination makes a natural association and provides unity to different perceptions.

Although Hume does not make any explanation, he leaves the relation of contiguity aside because it is not a relation that the imagination uses in shaping the idea of identity (Hume, 1960: 254). Contiguity is used by imagination to give unity to perceptions, but it is ineffective in producing identity. However, when we consider the role of the contiguity in the cause-effect of relation, it can be considered that it has an indirect influence in the production of the identity. As a matter of fact, it is possible to support this with the expressions of Hume like it has "no influence" or "little" influence (Hume, I960: 260). However, his not explaining contiguity in any way in the relations that produce identity shows his decisiveness. In this context, it may seem that there is a problem because contiguity is a relation used in the production of causation; but it is ineffective in the generation of identity. The explanations of Pears and Thiel offer a reasonable solution to this problem. According to Pears, causation here is not a spatial causality but a mental one. For this reason, the thing 
that generates it is not a spatial contiguity because some perceptions have no any physical location (Pears, I993: 295). Like Pears, Thiel also claimed that Hume thought that there were some perceptions that could not be said to exist somewhere in the space; and these perceptions made the contiguity principle useless for unifying of the perceptions in the identity issue (Thiel, 2OII: 394). Because identity is not a idea that is generated by imagination by perceiving the objects as constantly contiguity in space or in a place. Instead, the relations that form the identity in imagination by giving unity to ideas are resemblance and causation. Imagination loads identity to successive perceptions because of their resemblance or their causation that are assumed to exist between them. Thanks to the memory, the "images of past perceptions" are recalled; and the transition from one ring to another ring in the chain of ideas is facilitated via associations (Hume, I960: 260). It is impossible to speak of resemblances and causation without recalling the images of past perceptions. For this reason, if memory loses its functions, neither the idea of identity nor the idea of personal identity will be possible. In this respect, memory is the "source of personal identity" and the idea of identity.

Memory's being the source of personal identity does not mean that it generates it. For Hume, who showed that generation and discovery are two different things, the position of the memory is its being an explorer (Hume, I960: 262). Thanks to the memory, the resemblance relation between successive perceptions and the relation of causality between different perceptions are discovered. Like an explorer, the memory presents materials to the imagination; and becomes the source of personal identity. However, imagination expands its functioning "beyond our memory" by not being content with the things offered by the memory (Hume, 1960: 262). Although we do not remember what we did today three years ago, it goes beyond the memory by generating the same person as the present self. Therefore, the idea of personal identity is not a real idea; it is a "fictitious" (Hume, r960: 259) idea generated by the imagination by moving beyond the memory. Imagination generates personal identity by assigning an imaginary unity to the perceptions that have distinctive existence and that are remembered through the memory (Hume, I960: 262). While every perception is "different, distinguishable, 
and separable from every other perception" (Hume, I960: 259), loading the mind with identity is nothing more than a fictitious identity; because identity is not generated by sensing a real relation between perceptions. Instead, it "is merely a quality, which we attribute to them, because of the union of their ideas in the imagination, when we reflect upon them." (Hume, I960: 260). If Hume considered identity as a real relation between perceptions, he would contradict all his previous arguments on causality; and would have to accept an unchanging and uninterrupted self. However, Hume explains the identity (like in the causality) with the associative nature of imagery, claiming that "understanding never observes any real connexion among objects" (Hume, I960: 259-260). Because "no connexions among distinct existences are ever discoverable by human understanding. We only feel a connexion or determination of the thought, to pass from one object to another." (Hume, 1960: 635). For this reason, identity is not a discovered relation, like Hume emphasized and Baxter pointed out; it is a relation that is felt while thinking on the relation between perceptions (Baxter, 1998: 205). Otherwise, in the contrary situation, the identity had to be a product of the memory because Hume defined the memory as an explorer. The generation of identity by imagination reveals that both the identity and the continuous self are in fact a feel, and therefore, it is a belief. As a matter of fact, "belief is more properly an act of the sensitive, than of the cogitative part of our natures." (Hume, I960: I83). In this respect, we both believe in the existence of a continuous and simple self, just like we believe in the continued existence of external objects.

If a father's being a child at a time point in the past or his being fat a few months ago and having lost weight at present does not host a change in the identity despite the variable and interruption in the perceptions, the reason for this is that it is a kind of belief; or in other words, it is the assumption of the self, the soul and the substance. The same assumption is continued for plants and animals. "An oak, that grows from a small plant to a large tree, is still the same oak; tho' there be not one particle of matter, or figure of its parts the same." (Hume, I960: 257). An "unknown and mysterious" (Hume, 1960: 254) thing is fabricated to hide the change and difference in perceptions with this identity thought that is 
false and fictitious. This fictionalization is called "soul, self and substance" (Hume, 1960: 254) or "original and first matter" (Hume, I960: 220), just like assuming that the oak tree is a substance that makes it the oak tree. The change between the shoots of the oak tree and the oak tree itself causes that a contradiction is revealed in the thought of identity. In order to relieve from the contradiction formed by the difference between the perceptions, a fictional principle like the substance is accepted and believed to be the same despite the change. These assumptions, which will relieve the tension of the mind that stems from the contradiction, are also valid for the acceptance of the personal identity. ${ }^{2}$ While the mind is a collection of different but related successive of perceptions, loading a perfect identity on it means putting it in the same category as the substance; because the perfect identity requires an object that is uninterrupted and unchangeable, and the substance is the most appropriate counterpart for this.

The substance is an idea that we do not have any simple impression of like the self. For this reason, in fact we do not have a clear idea of the substance (Hume, I960: 15-16). If self or substance is mentioned, we need to have an idea attached to these terms and a corresponding impression for those ideas. However, "we have no impression of self or substance, as something simple and individual. We have, therefore, no idea of them in that sense." (Hume, I960: 633). If the thing called "self" is only the heap of perceptions, then which simple perception can be the source of the idea of a mental substance? Even if we assume that the mind has a life that is simpler than the life of an oyster, it is not possible to obtain a simple idea of the substance; because the mind's perception such as hunger or thirst, is insufficient for the idea of the self or substance. Therefore, Hume objected to the claims that the substance is a simple perception of the self because the self and the substance are thought as "distinct from the particular perceptions" (Hume, I960: 635). If a substance or a self is to be mentioned, this may only be with particular perceptions; or

\footnotetext{
2 The mind can be distended due to paradoxes and contradictions when it focuses on identity. It is very difficult to live with this tension. As Sokolowski states, we need to this belief to live, even if it is a fiction. For this reason, Hume asserts that self is a subjective illusion or fiction, and this illusion or fiction is "natural and necessary for human existence and action" (Sokolowski, 1968: 197).
} 
in other words, with distinct perceptions whose existence is different from each other. Hume, who developed a strong and skeptical perspective to the substance and self in history of philosophy, on the one hand, criticizes metaphysics in a serious manner, and on the other hand, provides a scientific and positive explanation of the human nature. Metaphysicians assume the substance as "a principle of union or cohesion" (Hume, I960: 22I), and name them with one single name to enable them to be mentioned as one single thing despite the variety of the different and distinctive perceptions. Metaphysicians who claim that this unity or the unifying principle is the substance, also accept the self as a mental substance. Hume claimed that the personal identity, and therefore, the concepts of self and substance are fiction and fictitious by asking if the unifying principle existed or not both in the Treatise I.4.6 and in the Appendix.

Although Hume stated that he was not satisfied with the unifying principle in the Appendix, he has not given up on his thoughts in Treatise I.4.6. Indeed, Hume knows that he cannot explain it with his theory of perception. Neither his perception theory nor the metaphysical explanations can explain "the principle, that unite our successive perception in our thought or consciousness." (Hume, I960: 636). He confesses that he feels himself in a "labyrinth" (Hume, I960: 633) because he has not been able to find any theories that gives satisfaction in this issue. He continues to claim that "all our distinct perceptions are distinct existences, and that the mind never perceives any real connexion among distinct existences." (Hume, I960: 636). If Hume had abandoned these skeptical principles or accepted that the mind perceived a real connection between perceptions, he could not deny the idea that the mind was more than a bundle of successive perceptions. For this reason, his objections are directed to the substantive theories of self in the thoughts on personal identity. Hume has taken his precautions for any metaphysical element that would leak into his theory of perception. He revealed a skeptical criticism that was nourished by the epistemology by explaining the mind with perceptions and by accepting that the self was identical to the mind. For this reason, the bundle theory of self is very important in terms of metaphysical criticism. With this theory, Hume explains why we tend to refer identity to our- 
selves despite different perceptions; and concludes a skeptical consequence against the personal identity. In this respect, a sufficient and convincing theory cannot be claimed to prove a false belief or a fiction for the thing that is called personal identity.

\section{Conclusion}

Hume focuses on self and identity investigations in the problem of personal identity. In the philosophy of Hume, in which he explained the self as a heap and a bundle of the perceptions that are distinct, distinguishable and may exist differently, which is known as the "bundle theory", investigates why we load identity to these perceptions, and why we assume that they belong to an invariable, continuous and the same self. Since the idea of self is a part of his epistemology, Hume explored the nature of this idea, and suggested that there is no simple impression of the idea of self as the result of the investigation. This result is the first skeptical result of Hume's personal identity investigation and is explained by bundle theory. As for the identity issue, the problems are becoming deeper for Hume. Identity is a condition which ensures that a relation is established between two ideas. In other words, identity is a feature we only load to it due to the unity in the imagination when we think about them. The problem is becoming more serious here because despite the different perceptions, there is no acceptable explanation of why imagination gave this unity. Assuming that the personal identity exists by uniting the perceptions means accepting that the self is a mental substance. This is an argument that Hume would refuse strongly, because Hume's perception theory does not allow it to be accepted. For this reason, Hume denies the idea of personal identity and explains it as the fiction of the imagination. This result is expected from Hume as a skeptical philosopher. Hume defended the thought that we cannot have a simple idea of self with his skeptical philosophy, and that identity is a fiction. These thoughts of Hume's suit well to the purpose he describes in the Introduction to the Treatise. Hume aimed to remove metaphysical elements from philosophy and give it a prestige. The argument that a real connection between the perceptions cannot be perceived is one of the arguments which caused that he placed a certain distance between his philosophy and metaphysical elements. Since identity does not arise from feeling a 
real connection between perceptions, it may be argued that the personal identity, which is based on identity, has reinforced Hume's thoughts about metaphysics. However, it may be argued that Hume's thoughts on personal identity are in line with his viewpoints on the nature of belief because Hume stated that personal identity is a feeling or sensation. Although human understanding cannot perceive any connection between distinct existences, it feels the connection of passing of the thought from one object to another. Since identity is a feeling, it is seen that both the identity and a continuous self are actually a belief. This skeptical result, which we recognize from the point where Hume questioned our belief in the external world that it existed as separately and independently, shows that the idea of personal identity is a belief; and for this reason, it does not have any rational sides.

\section{References}

Baxter, D. L. M. (1998). Hume's Labyrinth Concerning the Idea of Personal Identity. Hume Studies, XXIV (2), 203-234.

Capaldi, N. (1975). David Hume: The Neretonian Philosopher. Boston: Twayne Publishers.

Capaldi, N. (1995). Hume's Theory of the Self. David Hume: Critical Assessment, vol. III. (Ed. S. Tweyman). London \& New York: Routledge, 627-64I.

Hume, D. (1960). A Treatise of Human Nature. (Ed. L. A. Selby-Bigge). London: Oxford University Press.

Iannone, A. P. (200I). Dictionary of World Philosophy. London \& New York: Routledge.

Pears, D. (I993). Hume on Personal Identity. Hume Studies. XIX (2), 289-300.

Penelhum, T. (1975). Hume's Theory of the Self Revisited. Dialogue. I4, 389-409.

Robison, W. L. (1995). Hume on Personal Identity. David Hume: Critical Assessment, vol. III. (Ed. S. Tweyman). London \& New York: Routledge, 687-704.

Sokolowski, R. (1968). Fiction and lllusion in David Hume's Philosophy. The Modern Schoolman 45, XIV, I89-225.

Stroud, B. (1977). Hume. London and New York: Routledge.

Swain, C. G. (2006). Personal Identity and the Skeptical System of Philosophy. The Blackwell Guide to Hume's Treatise. (Ed. Saul Traiger). London: Blackwell 
Publishing, $133-150$.

Thiel, U.(201I). The Early Modern Subject: Self-Consciousness and Personal Identity from Descartes to Hume. Oxford: Oxford University Press.

Öz: Felsefede kișisel özdeșlik (kiși özdeșliği) problemi çoğu zaman bir özdeșlik problemi ya da benlik problemi olarak ele alınmaktadır. Özdeșlik problemi ile birlikte ele alındığında kișisel özdeșlik, belirli bir zamandaki kișinin bașka bir belirli zamandaki kișiyle aynı ve özdeș olarak kabul edilmesi anlamına gelmektedir. Benlik problemi ile birlikte ele alındığında ise kișisel özdeșlik tözsel ve metafiziksel bir sorușturmanın parçası gibi düșünülmektedir. Hume’un felsefesi kișisel özdeșlik tartışmalarının her iki durumunu da muhalif bir șekilde içermektedir. Bu çalıșmada Hume’un kișisel özdeșlik problemi hakkındaki düșünceleri araștırılacaktır. Öncelikle benlik tasarımının algıya dayalı epistemolojisindeki anlamı incelenecektir. Daha sonra ise özdeșlik ele alınacaktır. Hume'un benlik ve özdeșlik hakkındaki tezlerini olușturan șeyin onun skeptisizmi olduğu ve Hume’un bu sorușturmayla metafizik hakkındaki düșüncelerini pekiștirdiği iddia edilecektir. Bununla birlikte kișisel özdeșliğin daha iyi bir șekilde anlașılması için onun inancın doğası hakkındaki düşüncelerinin göz önünde bulundurulması gerektiği savunulacaktır.

Anahtar Kelimeler: Hume, kişisel özdeșlik, benlik, özdeșlik, demet teorisi, kușkuculuk. 


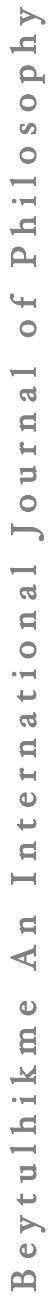

